Marquette University

e-Publications@Marquette

Chemistry Faculty Research and Publications

Chemistry, Department of

5-10-2013

\title{
Differential Hydrogen Bonding in Human CYP17 Dictates Hydroxylation versus Lyase Chemistry
}

Michael Gregory

University of Illinois at Urbana-Champaign

Piotr J. Mak

Marquette University, piotr.mak@marquette.edu

Stephen G. Sligar

University of Illinois at Urbana-Champaign

James R. Kincaid

Marquette University, james.kincaid@marquette.edu

Accepted version. Angewandte Chemie International Edition, Vol. 52, No. 20 (May 10, 2013):

5342-5345. DOI. (C) 2013 Wiley-VCH Verlag. Used with permission. 


\title{
Differential Hydrogen Bonding in Human CYP17 Dictates Hydroxylation versus Lyase Chemistry $^{* *}$
}

\author{
Michael Gregory \\ Department of Biochemistry, University of Illinois \\ Urbana, IL \\ Dr. Piotr J. Mak \\ Department of Chemistry, Marquette University \\ Milwaukee, WI \\ Prof. Stephen G. Sligar \\ Departments of Biochemistry and Chemistry, University of \\ Illinois \\ Urbana, IL \\ Prof. James R. Kincaid \\ Department of Chemistry, Marquette University \\ Milwaukee, WI
}


NOT THE PUBLISHED VERSION; this is the author's final, peer-reviewed manuscript. The published version may be accessed by following the link in the citation at the bottom of the page.

\begin{abstract}
:
Raman spectra of oxygenated intermediates of Nanodisc incorporated human CYP17 in the presence of natural substrates directly confirm that substrate structure effectively alters $\mathrm{H}$-bonding interactions with the critical Fe-O-O fragment so as to dictate its predisposition for one of two alternative reaction pathways, providing a realistic structural explanation for substrate control of CYP17 reactivity that has profound physiological implications.
\end{abstract}

Keywords: biophysics, heme proteins, oxidoreductases, Raman spectroscopy, lyase reaction.

CYP17A1 is a member of the cytochrome P450 superfamily that occupies a central role in the biosynthesis of steroid hormones. ${ }^{[1,2]}$ This enzyme catalyzes both the hydroxylation of its primary substrates pregnenolone and progesterone as well as the subsequent 17,20 carbon-carbon lyase chemistry which is the first committed step in the biosynthesis of androgens. ${ }^{[1-3]}$ There is significant debate as to the chemical mechanisms of this lyase activity, with human CYP17 exhibiting a significant preference for 17-hydroxy pregnenolone over 17-hydroxy progesterone. In vivo, the predominant pathway forming androgens proceeds through the conversion of hydroxypregnenolone to dehydroepiandrosterone. ${ }^{[4-6]}$ We report newly acquired resonance Raman ( $r R$ ) spectra of monomeric CYP17A1 self-assembled in Nanodiscs, which reveal a distinct difference in hydrogen bonding to the ferrous dioxygen intermediate. With 17-hydroxyprogesterone, the oxygen vibrational modes indicate hydrogen bonding to the distal oxygen of the Fe-O-O fragment, whereas with 17hydroxypregnenolone hydrogen bonding is to the proximal oxygen. To the extent that such interactions persist in the subsequent peroxointermediate, the latter interaction is expected to inhibit $\mathrm{O}-\mathrm{O}$ bond cleavage relative to the former, permitting nucleophilic attack of the peroxo intermediate on the 20-carbonyl. This observation of differential $\mathrm{H}$-bonding interactions, alone, satisfactorily explains the dramatically lower activity of the $\Delta-4$ progesterone substrate relative to that of the $\Delta-5$ pregnenolone compound in androgen biosynthesis. These results constitute a definitive experimental confirmation of the role of substrate structure in directly controlling the metabolic 
processing of these dual function cytochrome P450s and support the role of the peroxoanion in maintaining high lyase activity.

The cytochromes P450 (CYPs) are heme-containing monooxygenases that participate in a wide range of physiologically important processes in both eukaryotic and prokaryotic organisms. [7] In vertebrates, one essential function of CYPs is the transformation of cholesterol into steroid hormones through the involvement of highly stereo- and regio-specific reactions ultimately yielding the corticoids, androgens, and estrogens. ${ }^{[1-3]}$ These steroidogenic P450s act on a select number of compounds, some catalyzing only hydroxylation chemistry, with others also active in carbon-carbon bond cleavage. The chemical intermediates responsible for this variable reactivity have been the subject of much debate, yielding questions as to how these enzymes control multi-state oxidative transformations. ${ }^{[8,9]}$

The membrane bound CYP17 lies at the heart of steroid metabolism where it carries out standard monooxygenase chemistry, converting pregnenolone (PREG) and progesterone (PROG), to $17 \mathrm{a}-\mathrm{OH}$ pregnenolone (OH-PREG) and 17a-OH progesterone (OH-PROG), respectively, apparently utilizing a "Compound I" to initiate hydrogen abstraction and radical recombination in the classic "Groves rebound" mechanism. ${ }^{[7-10]}$ However, these hydroxylated products can also serve as substrates in a second oxidative cycle to cut the 17-20 carboncarbon bond to form dehydroepiandrosterone and androstenedione (Figure 1). ${ }^{[1,2]}$ This reaction represents a critical branch point in human steroidogenesis at which the hydroxylated products of CYP17 are either shunted towards production of corticoids or subjected to a second round of catalysis that constitutes the first committed step of androgen formation. not grant permission for this article to be further copied/distributed or hosted elsewhere without the express permission from Wiley-VCH Verlag. 
<smiles>C=C(C)C1CCC2C3CCC4=CC(=O)CCC4(C)C3CCC12C</smiles><smiles></smiles>

$17 \alpha$-hydroxy progesterone (17-OH PROG)

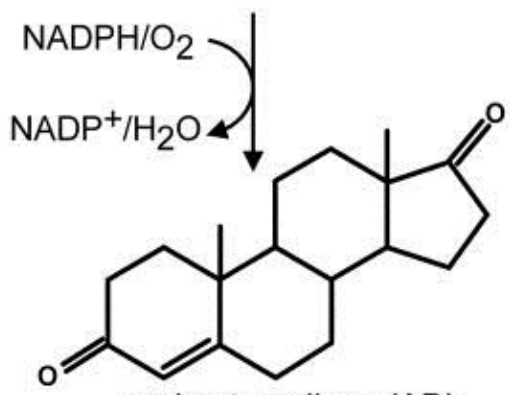
androstenedione $(A D)$<smiles>C=C(C)C1CCC2C3CC=C4CC(O)CCC4(C)C3CCC12COc1ccco1</smiles><smiles></smiles>

$17 \alpha$-hydroxy pregnenolone (17-OH PREG)

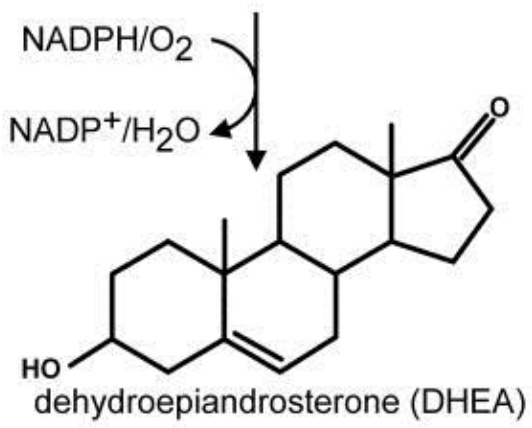

Figure 1 The proposed pathway for biosynthesis of androstenedione and dehydroepiandrosterone catalyzed by human CYP17A1. The full enzymatic cycle is shown in Supporting Information, Figure S1.

Clearly, elucidating the factors that control CYP17 product formation is crucial for understanding healthy and diseased human physiology. Particularly intense scrutiny of the $\mathrm{C}-\mathrm{C}$ lyase activity of this enzyme has led to suggestions that nucleophilic attack on the C-20 carbonyl by the early peroxo-ferric intermediate is utilized in the formation of androgens. ${ }^{[11-13]}$ This led us to seek structural features of the active site that could control a branch point between $\mathrm{O}-\mathrm{O}$ bond scission/Compound I formation versus a heme-oxygen intermediate reactive in $\mathrm{C}-\mathrm{C}$ lyase chemistry. Since androgen formation is 50 -fold 
greater with $\mathrm{OH}-\mathrm{PREG}$ than for OH-PROG, this substrate pair was used for our investigations. ${ }^{[4,6,14,15]}$

An important step towards the understanding of androgen formation was the recently reported crystal structure by DeVore and Scott of human CYP17A1 in complex with promising anti-cancer drugs. ${ }^{[16]}$ These authors used molecular modeling to suggest that interactions of the $3 \beta$-alcohol or corresponding ketone fragments of PREG and PROG with active site $\mathrm{H}$-bonding residues place the substrate in correct orientation with respect to the heme prosthetic group, also making the point that the active site topology might be altered by substrates and stressed the pressing need for further experimental work. ${ }^{[16]}$

The Nanodisc system allows functional incorporation of these membrane proteins into homogenous and monodisperse membrane environments to yield exceptionally well-behaved ligand binding properties, showing clean conversions of spin-state populations, and also enhances stability of their dioxygen adducts. ${ }^{[17-20]}$ Combination of this system with the power of $\mathrm{rR}$ spectroscopy to interrogate active site structure in heme proteins presents an especially effective approach to explore the complex mechanism of CYP17A1. Specifically addressed in this report is a particularly intriguing aspect of CYP17A1 structure, wherein the choice of substrate controls hydrogen bonding that defines the catalytic channel for product formation. ${ }^{[4-6,15]}$ Herein $\mathrm{rR}$ spectroscopy convincingly demonstrates that the single difference at the $3 \beta$ position of OH-PREG and OH-PROG leads to unequivocal changes in active site $\mathrm{H}$-bonding interactions with the key $\mathrm{Fe}-\mathrm{O}-\mathrm{O}$ fragment of enzymatic intermediates, leading to alterations in electronic structure that then control substrate processing.

Shown in Figure 2A are the rR spectra obtained for the ${ }^{16} \mathrm{O}_{2}$ adduct of PROG-bound CYP17. In addition to structure-sensitive heme modes, including $\mathrm{v}_{4}, \mathrm{v}_{3}$, and $\mathrm{v}_{2}$, the key $\mathrm{v}\left({ }^{16} \mathrm{O}-{ }^{16} \mathrm{O}\right)$ mode is observed at $1140 \mathrm{~cm}^{-1}$, as confirmed by the uncluttered ${ }^{16} \mathrm{O}_{2} /{ }^{18} \mathrm{O}_{2}$ difference spectrum. The $v(\mathrm{Fe}-\mathrm{O})$ stretching mode appears at $536 \mathrm{~cm}^{-1}$, as documented in the ${ }^{16} \mathrm{O}_{2} /{ }^{18} \mathrm{O}_{2}$ difference trace (Figure $2 \mathrm{~A}$ ). These frequencies for the $\mathrm{Fe}-\mathrm{O}-\mathrm{O}$ fragment are quite similar to those observed when this fragment is weakly $\mathrm{H}$-bonded to $\mathrm{P} 450$ active site residues. ${ }^{[21,22]}$ Significantly, spectra acquired for this sample in 
solutions prepared in $\mathrm{D}_{2} \mathrm{O}$ (left and right traces in lower section of Figure $2 \mathrm{~A}$ ) showed no difference for this non-H-bonding substrate.

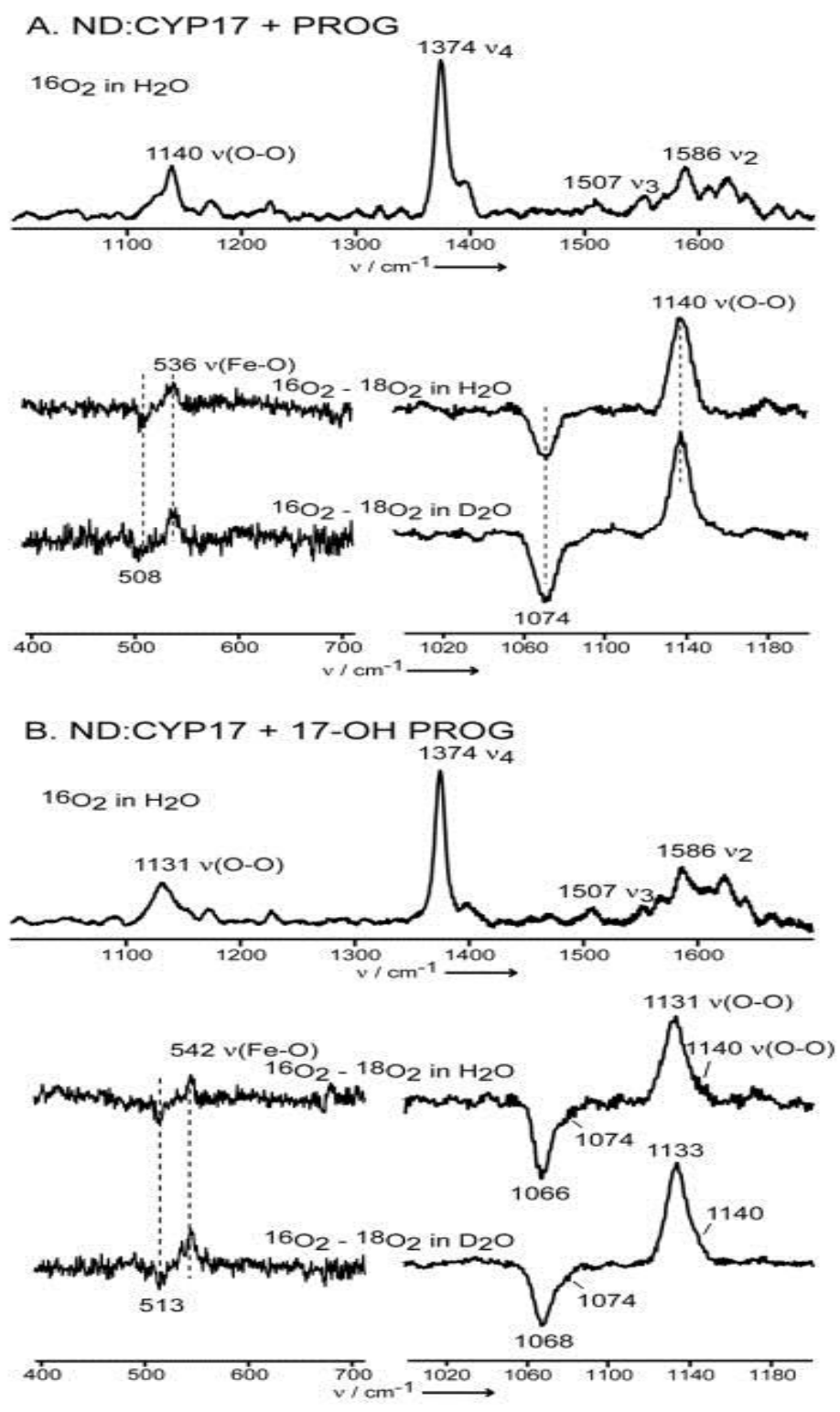

Figure 2 The rR spectra of PROG and $17-\mathrm{OH}-\mathrm{PROG}$ bound ${ }^{16} \mathrm{O}_{2}$ adducts of ND:CYP17 in $\mathrm{H}_{2} \mathrm{O}$ buffer (panel $A$ and $B$, respectively). The lower section of each panel shows ${ }^{16} \mathrm{O}_{2}-{ }^{18} \mathrm{O}_{2}$ difference plots in $\mathrm{H}_{2} \mathrm{O}$ (upper) and $\mathrm{D}_{2} \mathrm{O}$ (lower) buffers.

Shown in Figure $2 \mathrm{~B}$, top trace, is the $\mathrm{rR}$ spectrum obtained for the ${ }^{16} \mathrm{O}_{2}$ adduct of CYP17 harboring OH-PROG at its active site. The $\mathrm{v}\left({ }^{16} \mathrm{O}-{ }^{16} \mathrm{O}\right)$ mode now appears $\sim 9 \mathrm{~cm}^{-1}$ lower at $1131 \mathrm{~cm}^{-1}$. Expansion

Angewandte Chemie International Edition, Vol. 52, No. 20 (May 2013): pg. 5342-5345. DOI. This article is (C) Wiley-VCH Verlag and permission has been granted for this version to appear in e-Publications@Marquette. Wiley-VCH Verlag does not grant permission for this article to be further copied/distributed or hosted elsewhere without the express permission from Wiley-VCH Verlag. 
of this spectral region, and comparison with the spectrum acquired with ${ }^{18} \mathrm{O}_{2}$, shows evidence for a minor conformer that is apparently quite similar to the form observed when PROG is bound (Figure 2A). As is evidenced by a telltale $2 \mathrm{~cm}^{-1}$ shift to higher frequency in solutions prepared in $\mathrm{D}_{2} \mathrm{O},{ }^{[21]}$ the dominant form, occurring at 1131 $\mathrm{cm}^{-1}$, is $\mathrm{H}$-bonded (Figure $2 \mathrm{~B}$, lower right). It is most reasonable to attribute the clearly observed $\mathrm{H}$-bonding interaction to the newly introduced $\mathrm{C}_{17}-\mathrm{OH}(\mathrm{D})$ functionality; note that this lowering of the $\mathrm{v}(\mathrm{O}$ O) mode is correlated with a corresponding $6 \mathrm{~cm}^{-1}$ increase in the frequency of the $\mathrm{v}(\mathrm{Fe}-\mathrm{O})$ band relative to its value in the PROG-bound enzyme.

Corresponding spectral data for the PREG and 17-OH-PREGbound enzymes are shown in Figure 3. As for the PROG-bound enzyme, the $\mathrm{v}(\mathrm{O}-\mathrm{O})$ and $\mathrm{v}(\mathrm{Fe}-\mathrm{O})$ modes of the PREG-bound enzyme are observed near 1140 and $535 \mathrm{~cm}^{-1}$ with no evidence for $\mathrm{H}$-bonding. As shown in Figure 3B, for the OH-PREG sample, the $\mathrm{v}(\mathrm{O}-\mathrm{O})$ mode is shifted down by only $5 \mathrm{~cm}^{-1}$ compared with its value for the PREGbound form and exhibits a barely detectable upshift in deuterated solvents. Now however, the $\mathrm{v}(\mathrm{Fe}-\mathrm{O})$ is observed at $526 \mathrm{~cm}^{-1}$, exhibiting a $9 \mathrm{~cm}^{-1}$ shift to lower frequency compared to the value observed for the sample containing non-H-bonding PREG. The main point is that rather dramatic differences are observed when comparing the samples bound with OH-PROG and OH-PREG. Though introduction of the 17-OH group causes downshifts of the $\mathrm{v}(\mathrm{O}-\mathrm{O})$ modes for both $\mathrm{OH}-\mathrm{PROG}$ and $\mathrm{OH}-\mathrm{PREG}$, the corresponding $\mathrm{v}(\mathrm{Fe}-\mathrm{O})$ modes shift in opposite directions; i.e., the 17-OH-PROG yields a $6 \mathrm{~cm}^{-1}$ upshift while the 17-OH-PREG shows a $9 \mathrm{~cm}^{-1}$ downshift. It is emphasized that $\mathrm{rR}$ spectra acquired with $356 \mathrm{~nm}$ excitation for all four samples showed no evidence for changes in the trans Fe-S bond strength (data not shown), indicating that the effects on the Fe-O-O fragment arise mainly from distal side interactions. 
A. ND:CYP17 + PREG

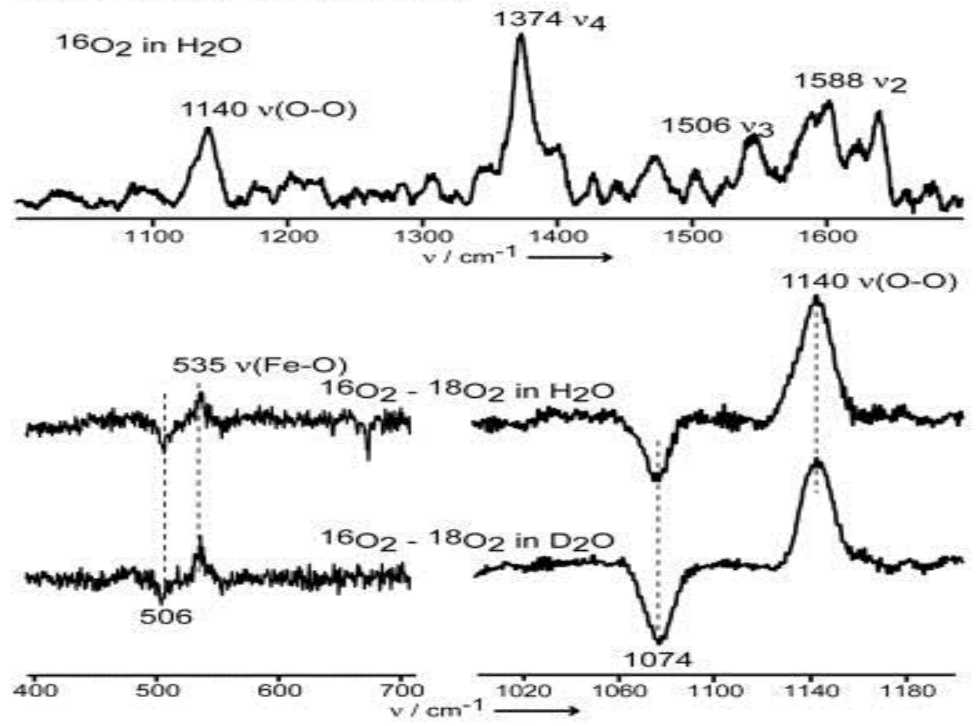

B. ND:CYP17 + 17-OH PREG

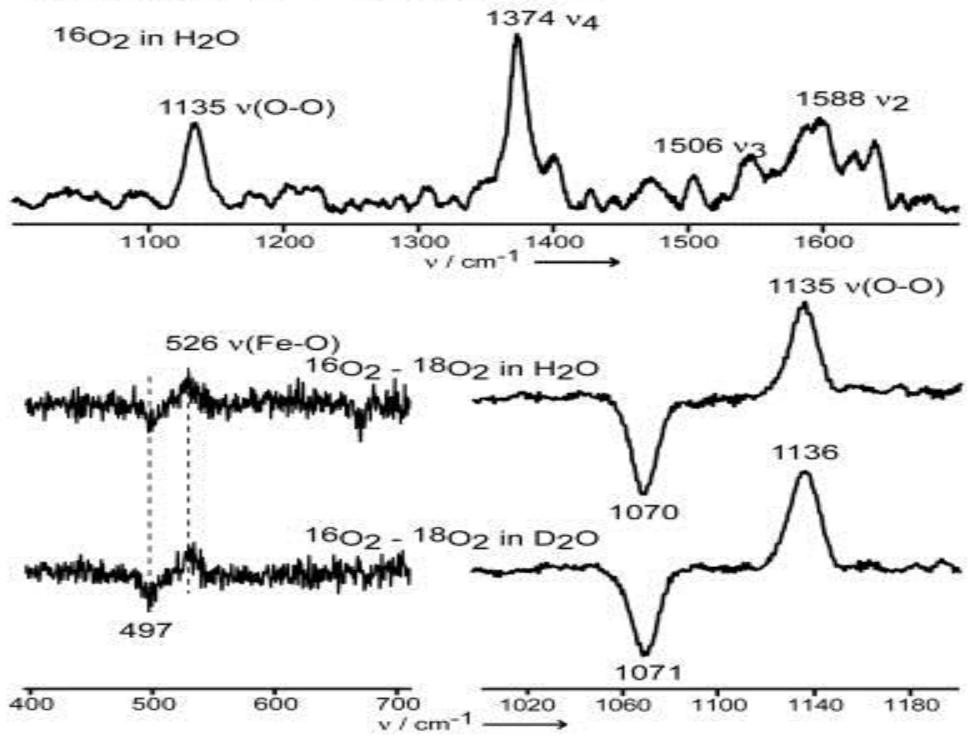

Figure 3 The rR spectra of PREG and 17-OH-PREG bound ${ }^{16} \mathrm{O}_{2}$ adducts of ND:CYP17 in $\mathrm{H}_{2} \mathrm{O}$ buffer (panel $A$ and $B$ respectively). The lower section of each panel shows ${ }^{16} \mathrm{O}_{2}-{ }^{18} \mathrm{O}_{2}$ difference plots in $\mathrm{H}_{2} \mathrm{O}$ (upper) and $\mathrm{D}_{2} \mathrm{O}$ (lower) buffers.

While reference data for the vibrational modes of dioxygen adducts of heme proteins are relatively scarce certain fundamental patterns have emerged. ${ }^{[21-26]}$ Studies of globin mutants indicate that $\mathrm{H}$-bonds to the inner (proximal) $\mathrm{O}$ of the $\mathrm{Fe}-\mathrm{O}-\mathrm{O}$ fragment cause a decrease in the $\mathrm{v}(\mathrm{Fe}-\mathrm{O})$ mode, with similar but smaller effects on the

Angewandte Chemie International Edition, Vol. 52, No. 20 (May 2013): pg. 5342-5345. DOI. This article is @ Wiley-VCH Verlag and permission has been granted for this version to appear in e-Publications@Marquette. Wiley-VCH Verlag does not grant permission for this article to be further copied/distributed or hosted elsewhere without the express permission from Wiley-VCH Verlag. 
$\mathrm{v}(\mathrm{O}-\mathrm{O})$; i.e., a positive correlation, ${ }^{[23]}$ whereas $\mathrm{H}$-bonding to the outer (terminal) $\mathrm{O}$ often leads to significant lowering of the $\mathrm{v}(\mathrm{O}-\mathrm{O})$ fragment in P450s and related enzymes. ${ }^{[21,24-26]}$ Importantly, recent DFT calculations on histidine-ligated oxy complexes predict that, ${ }^{[22]}$ other factors being held constant, $\mathrm{H}$-bond donation to the proximal oxygen atom $\left(\mathrm{O}^{\mathrm{P}}\right)$ will weaken both bonds by withdrawing of electrons into the non-bonding $\mathrm{sp}^{2}$ orbital on the $\mathrm{O}^{\mathrm{P}}$, causing both the $\mathrm{v}(\mathrm{Fe}-\mathrm{O})$ and the $\mathrm{v}(\mathrm{O}-\mathrm{O})$ modes to shift in concert to lower frequency. In contrast, $\mathrm{H}-$ bond donation to the terminal oxygen, $\mathrm{O}^{\top}$, results in a straightforward increase in back-bonding; i.e., one expects a negative correlation, where the $\mathrm{v}(\mathrm{O}-\mathrm{O})$ decreases while the $\mathrm{v}(\mathrm{Fe}-\mathrm{O})$ increases. Therefore, collectively, these $\mathrm{r} R$ results provide convincing evidence that the two hydroxylated substrates interact at opposite ends of the $\mathrm{Fe}-\mathrm{O}-\mathrm{O}$ fragment, as depicted in Figure 4, leading to crucial implications for CYP17A1 function; i.e., it is anticipated that these interactions will dictate the preference for the hydroxylation and lyase pathways. Such $\mathrm{H}$-bonding interactions with $\mathrm{O}^{\top}$ are expected to promote $\mathrm{O}-\mathrm{O}$ bond

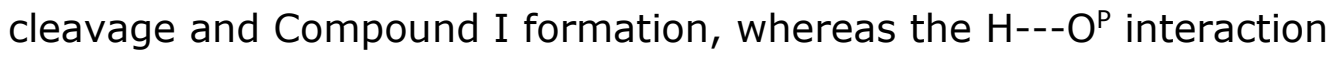
should prolong the lifetime of the ferric peroxo- intermediate that is suggested to be the active fragment in the lyase reaction. ${ }^{[27,28]}$ Indeed, such differences in $\mathrm{O}^{\top}$ vs $\mathrm{O}^{\mathrm{P}} \mathrm{H}$-bonding interactions have been invoked for the nitric oxide synthase reaction; in the first cycle the arginine substrate is suggested to provide a $\mathrm{H}---\mathrm{O}^{\top}$ interaction and facilitate Compound I formation, whereas in the second cycle the hydroxylated substrate (NOHA) is believed to provide a $\mathrm{H}---\mathrm{O}^{\mathrm{P}}$ interaction and proceed through a peroxo-intermediate. ${ }^{[26,29,30]}$ not grant permission for this article to be further copied/distributed or hosted elsewhere without the express permission from Wiley-VCH Verlag. 
A. ND:CYP17 + 17-OH PROG

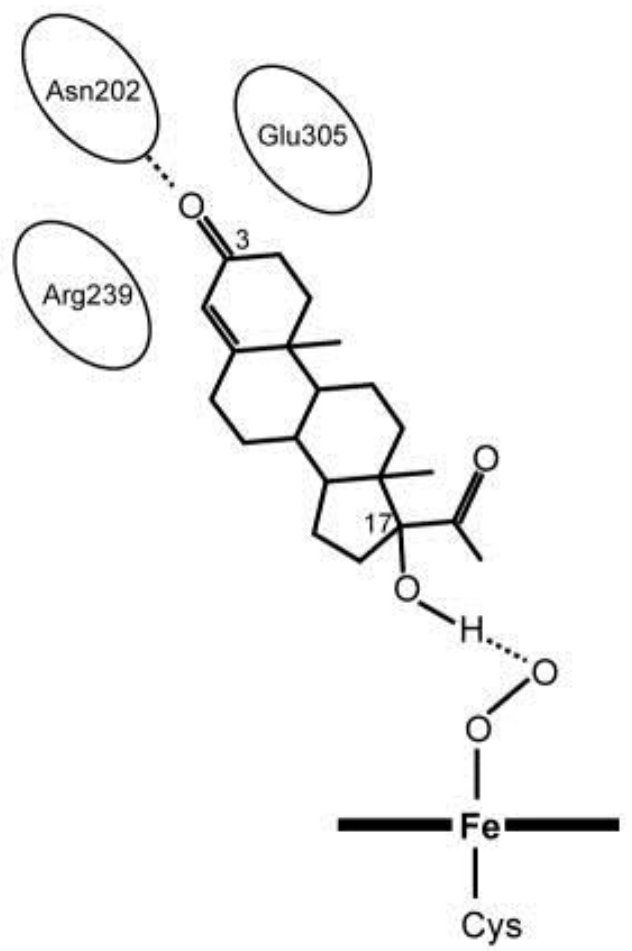

B. ND:CYP17 + 17-OH PREG



Figure 4 Graphical representation of human CYP17A1 protein substrate interaction derived from these newly acquired $r R$ data.

In summary, rR spectra of Nanodisc incorporated CYP11A1 clearly define the active site hydrogen bonding, where the only change being compared is a difference between a $3 \beta-\mathrm{OH}$ group vs a corresponding ketone in natural CYP17A1 substrates. Significantly, this single difference at a relatively remote site is sufficient to alter the $\mathrm{H}$ bonding interactions with the critical Fe-O-O fragment in such a way as to dictate its predisposition towards one of two alternative reaction pathways. Though providing a structural explanation for the differential reactivity of CYP17A1 substrates is itself a significant contribution, the present results also convincingly illustrate the impressive power of rR spectroscopy to identify localized structural interactions that dictate reactivity patterns within the enzymatic cycles of cytochromes P450 and related systems.

Angewandte Chemie International Edition, Vol. 52, No. 20 (May 2013): pg. 5342-5345. DOI. This article is (C Wiley-VCH Verlag and permission has been granted for this version to appear in e-Publications@Marquette. Wiley-VCH Verlag does not grant permission for this article to be further copied/distributed or hosted elsewhere without the express permission from Wiley-VCH Verlag. 
NOT THE PUBLISHED VERSION; this is the author's final, peer-reviewed manuscript. The published version may be accessed by following the link in the citation at the bottom of the page.

\section{Experimental Section}

Full length human CYP17A1 was expressed from a synthetic gene in $\mathrm{DH} 5 \mathrm{a}$ co-transformed with the GroEL/ES chaperone system (Takara Bio), purified to electrophoretic homogeneity and incorporated into Nanodiscs as previously described [31-33] and are summarized in details in Supporting Information. Resonance Raman spectra of frozen samples were obtained using the $413.1 \mathrm{~nm}$ excitation line from a $\mathrm{Kr}^{+}$ laser, which effectively enhances heme modes and internal modes of the Fe-O-O fragment (see Supporting Information for details). The spectra were calibrated with fenchone (Sigma-Aldrich, WI) and processed with Grams/32 AI software (Galactic Industries, Salem, $\mathrm{NH}$ ).

\section{Supplementary Material}

\section{Supporting Information}

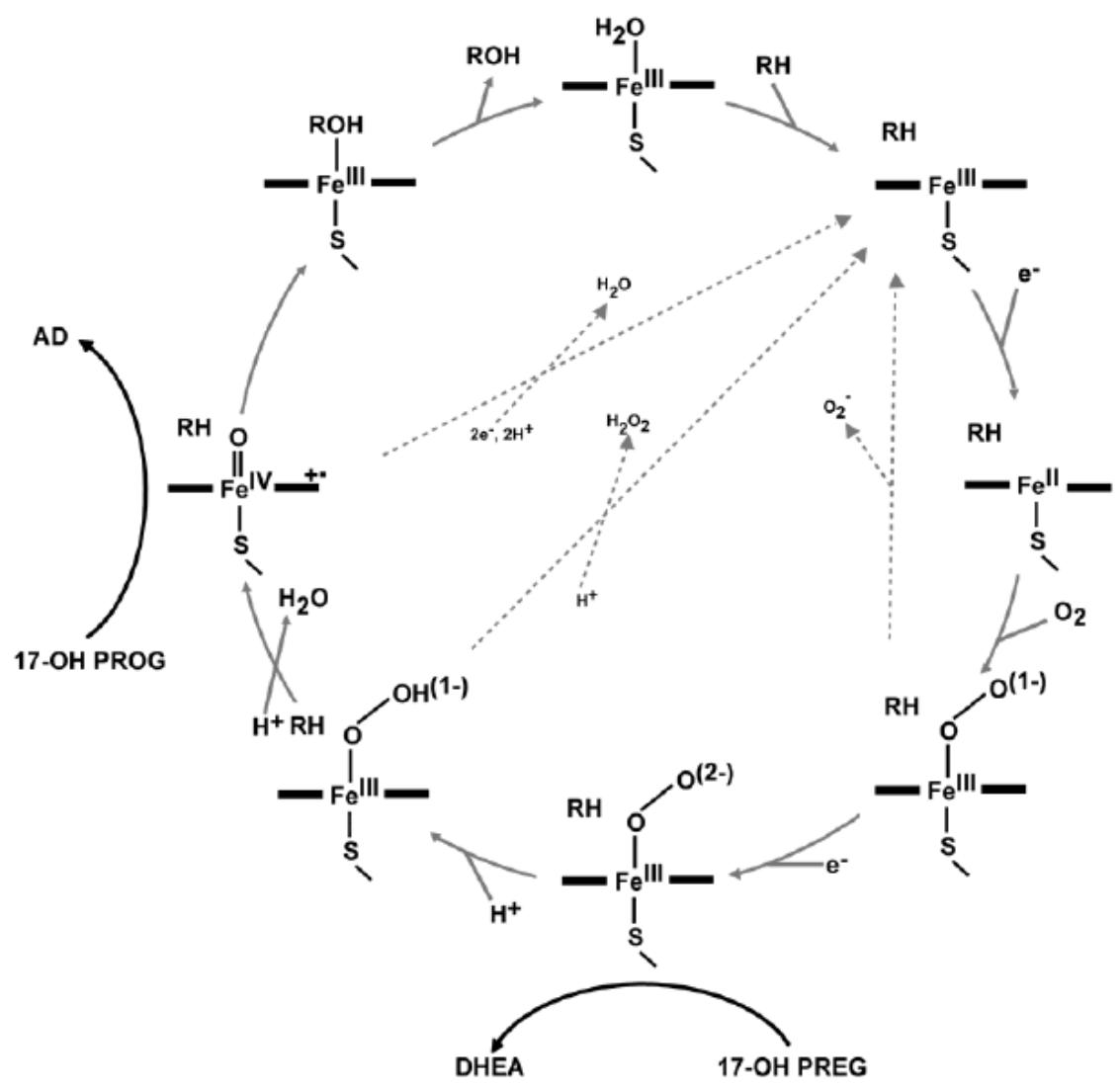

Angewandte Chemie International Edition, Vol. 52, No. 20 (May 2013): pg. 5342-5345. DOI. This article is (C) Wiley-VCH Verlag and permission has been granted for this version to appear in e-Publications@Marquette. Wiley-VCH Verlag does not grant permission for this article to be further copied/distributed or hosted elsewhere without the express permission from Wiley-VCH Verlag. 
NOT THE PUBLISHED VERSION; this is the author's final, peer-reviewed manuscript. The published version may be accessed by following the link in the citation at the bottom of the page.

Figure S1. The enzymatic cycle of cytochrome P450s. Note that the reaction shown for 17-OH PROG also occurs for PROG and PREG.

\section{Experimental Section}

\section{Protein preparation}

\subsection{Detailed Purification of CYP17A1}

Frozen cell pellets, typically $25-30 \mathrm{~g} / \mathrm{L}$, from $6 \mathrm{~L}$ culture were resuspended in $270 \mathrm{~mL}$ Buffer $\mathrm{A}$ (0.1 M potassium phosphate $\mathrm{pH} 7.4$, $0.05 \mathrm{M} \mathrm{NaCl}, 20 \%$ glycerol, $50 \mu \mathrm{M}$ progesterone, $10 \mathrm{mM} \beta-\mathrm{Me}, 0.5 \mathrm{mM}$ PMSF, $0.1 \mathrm{mg} / \mathrm{mL}$ lysozyme, $0.1 \mathrm{mg} / \mathrm{mL}$ DNase, $0.1 \mathrm{mg} / \mathrm{mL}$ RNase). Lysate was stirred at $4^{\circ} \mathrm{C}$ for 60 minutes. Resultant spheroplasts were lysed by sonication using a Branson Sonifier 450 attached to a $0.5 \mathrm{~cm}$ probe with six, two-minute cycles at 0.6 power and $70 \%$ duty cycle.

Lysate was centrifuged at $100,00 \mathrm{~g}$ for 30 minutes at $4^{\circ} \mathrm{C}$. The supernatant was discarded and membrane pellets resuspended in $270 \mathrm{~mL}$ Buffer B (0.1 M potassium phosphate $\mathrm{pH} 7.4,0.5 \mathrm{M} \mathrm{NaCl}, 20 \%$ glycerol, $50 \mu \mathrm{M}$ Progesterone, $10 \mathrm{mM} \beta-\mathrm{Me}, 0.5 \mathrm{mM}$ PMSF) by stirring for 1 hour at $4^{\circ} \mathrm{C}$. To solubilize membrane associated proteins, $20 \%$ Triton X-100 was added dropwise until the final detergent concentration reached $1.5 \%$. This solution was incubated at $4{ }^{\circ} \mathrm{C}$ while stirring for 1 hour, and was then centrifuged at $100,000 \mathrm{~g}$ for 30 minutes at $4^{\circ} \mathrm{C}$. Supernatant containing solubilized membrane proteins was collected and the insoluble membrane fraction discarded.

The solubilized fraction was immediately loaded onto a Ni-NTA column equilibrated with 4 column volumes of Buffer $B$ containing $1.5 \%$ Triton $\mathrm{X}-100$ and washed with 5 column volumes of Buffer $\mathrm{C}$ (0.05 M Tris, $\mathrm{pH} 7.4,0.3 \mathrm{M} \mathrm{NaCl}, 20 \%$ glycerol, $50 \mu \mathrm{M}$ progesterone, $0.02 \%$ Emulgen 913, $10 \mathrm{mM} \beta-\mathrm{Me})$. Next, the column was washed with 10 column volumes of Buffer $C$ containing $50 \mathrm{mM}$ imidazole, $5 \mathrm{mM}$ adenosine triphosphate, and $20 \mathrm{mM} \mathrm{MgCl}$. Bound protein was eluted with 2 column volumes of Buffer $\mathrm{C}$ with $300 \mathrm{mM}$ imidazole and collected in $4 \mathrm{~mL}$ fractions. Colored fractions were pooled and dialyzed once overnight against $1 \mathrm{~L}$ of $0.1 \mathrm{M}$ potassium phosphate $\mathrm{pH} 7.4,20 \%$ glycerol, $0.05 \mathrm{M} \mathrm{NaCl}, 50 \mu \mathrm{M}$ progesterone, $10 \mathrm{mM} \mathrm{B-Me}$, and $2 \mathrm{mM}$ EDTA at $4^{\circ} \mathrm{C}$ in a $10,000 \mathrm{MWCO}$ membrane, and twice against the 
NOT THE PUBLISHED VERSION; this is the author's final, peer-reviewed manuscript. The published version may be accessed by following the link in the citation at the bottom of the page.

same buffer without EDTA. Finally, protein was concentrated to 50 $\mu \mathrm{M}$, flash frozen in liquid $\mathrm{N} 2$, and stored at $-80^{\circ} \mathrm{C}$.

\subsection{Nanodisc Incorporation of CYP17A1}

In order to interrogate the membrane bound CYP17A1 enzyme by $\mathrm{rR}$ without the deleterious effects of detergents, purified protein was self-assembled into the lipid bilayer of Nanodiscs. These nanoscale, discoidal, and monodisperse particles consist of a lipid bilayer solubilized by an encircling amphipathic scaffold protein (MSP1D1). Detailed protocols for the incorporation of a variety of membrane proteins, including CYP17A1, into Nanodiscs have been previously reported.[1]

Breifly, dried 1-palmitoyl-2-oleoyl-sn-glycero-3-phosphocholine (POPC) was resuspended in $0.1 \mathrm{M}$ potassium phosphate, $\mathrm{pH} 7.4$ and $0.05 \mathrm{M} \mathrm{NaCl}$. Triton $\mathrm{X}-100$ was added in a 1.15:1 molar ratio of detergent to lipid and complete solubilization of POPC was assisted by 30 minutes of sonication in a $60^{\circ} \mathrm{C}$ water bath. Purified CYP17A1 and His-tag cleaved MSP1D1 were added such that the final ratio of CYP17A1:MSP1D1:POPC:Triton X-100 was 1:10:650:748. Following a 30 minute incubation on ice, self-assembly of Nanodics was initiated by addition of $1 \mathrm{~g}$ Amberlite XAD-2 per milliliter of reconstitution solution. After a 5 hour incubation at $4^{\circ} \mathrm{C}$, Amberlite was removed by filtration and Nanodiscs containing embedded CYP17A1 were isolated on a Ni-NTA column. Properly formed discs were purified on a Superdex 200 10/300 GL column (GE Life Sciences), and stored at $80^{\circ} \mathrm{C}$ until use in $0.1 \mathrm{M}$ potassium phosphate buffer containing $15 \%$ glycerol (v/v).

\subsection{Preparation of samples for $r R$ measurements}

Samples for rR spectroscopy contained $100 \mu \mathrm{M}$ CYP17: Nanodiscs, 0.1 M potassium phosphate, $\mathrm{pH} 7.4,0.25 \mathrm{M} \mathrm{NaCl}$, and $400 \mu \mathrm{M}$ of progesterone or 17a-hydroxyprogesterone (Sigma). Solutions were prepared in either distilled $30 \%(\mathrm{v} / \mathrm{v})$ glycerol in $\mathrm{H} 2 \mathrm{O}$ or $30 \%(\mathrm{v} / \mathrm{v})$ glycerol-d3 in D2O, and were de-aerated under argon for 5 minutes. Samples were reduced under anaerobic conditions with a 1.5 fold molar excess of sodium dithionite in the presence of $2.5 \mu \mathrm{M}$ methyl-viologen. Each sample reduced for 10 minutes at room temperature and was transferred to a dry ice-ethanol bath held at -15

Angewandte Chemie International Edition, Vol. 52, No. 20 (May 2013): pg. 5342-5345. DOI. This article is @ Wiley-VCH Verlag and permission has been granted for this version to appear in e-Publications@Marquette. Wiley-VCH Verlag does not grant permission for this article to be further copied/distributed or hosted elsewhere without the express permission from Wiley-VCH Verlag. 
${ }^{\circ} \mathrm{C}$ where it was cooled for 1 minute. Oxy-ferrous complexes were formed by bubbling 1602 or 1802 for 5 seconds, followed by rapid freezing in liquid N2.

\section{The $r R$ measurements:}

The resonance Raman spectra of oxy complexes of Nanodiscincorporated CYP17A1 were acquired using a Spex 1269 spectrometer equipped with a Spec-10 LN-cooled detector having 2048 pixels (Princeton Instruments, NJ). The data were measured with $413.1 \mathrm{~nm}$ excitation line from a $\mathrm{Kr}+$ laser (Coherent Innova Sabre Ion Laser) The rR spectra were collected using back scattering $\left(180^{\circ}\right)$ geometry with the laser beam being focused by a cylindrical lens to form a line image on the sample. The laser power was adjusted to $1 \mathrm{~mW}$ or less. All measurements were done at $77 \mathrm{~K}$ and total collection time was 4-5 hrs in the high frequency region and 6-7 hrs in the low frequency region. The slit width was set at $150 \mu \mathrm{m}$ and the $1200 \mathrm{~g} / \mathrm{mm}$ grating were used; the linear reciprocal dispersion is $0.655 \mathrm{~nm} / \mathrm{mm}$ near $400 \mathrm{~nm}$, corresponding to $0.46 \mathrm{~cm}-1 /$ pixel. The spectral resolution was determined to be $4.1 \mathrm{~cm}-1$. The frozen samples were contained in 5 mm O.D. NMR tubes (WG-5 ECONOMY, Wilmad). The NMR tubes were positioned into a double-walled quartz low temperature cell filled with liquid nitrogen. The sample tubes were spun to avoid local heating. Spectra were calibrated with fenchone (Sigma-Aldrich, WI) and processed with Grams/32 AI software (Galactic Industries, Salem, $\mathrm{NH})$.

\section{References}

[S1] A. Luthra, M. Gregory, Y. V. Grinkova, I. G. Denisov, S. G. Sligar, S. G. Cytochrome P450 Protocols, Methods in Molecular Biology Vol. 987 (Ed.: I. R. Phillips), Ch. 10, Springer Science, 2013

\section{Footnotes}

**This work was supported by National Institutes of Health grants GM31756 to S.G.S. and R01GM96117 to J.R.K.

Supporting information for this article is available on the WWW under http://www.angewandte.org or from the author.

Angewandte Chemie International Edition, Vol. 52, No. 20 (May 2013): pg. 5342-5345. DOI. This article is @ Wiley-VCH Verlag and permission has been granted for this version to appear in e-Publications@Marquette. Wiley-VCH Verlag does not grant permission for this article to be further copied/distributed or hosted elsewhere without the express permission from Wiley-VCH Verlag. 
NOT THE PUBLISHED VERSION; this is the author's final, peer-reviewed manuscript. The published version may be accessed by following the link in the citation at the bottom of the page.

\section{Contributor Information}

Michael Gregory, Department of Biochemistry, University of Illinois, Urbana, IL 61801 (USA)

Dr. Piotr J. Mak, Department of Chemistry, Marquette University, Milwaukee, WI 53233 (USA), Fax: 4142887066.

Prof. Stephen G. Sligar, Departments of Biochemistry and Chemistry, University of Illinois, Urbana, IL 61801 (USA), Fax: 217265 4073.

Prof. James R. Kincaid, Department of Chemistry, Marquette University, Milwaukee, WI 53233 (USA), Fax: 4142887066.

\section{References}

1. Sigel A, Sigel H, Sigel RKO, editors. Metal Ions in Life Sciences. Vol. 3. John Wiley \& Sons, Ltd; Chichester: 2007.

2. Ortiz de Montellano PR, editor. Cytochrome P450: Structure, Mechanism and Biochemistry. 3. Kluwer/Plenum; New York: 2004.

3. Miller WL, Auchus RJ. Endocr Rev. 2011;32:81-151.

4. Auchus RJ, Lee TC, Miller WL. J Biol Chem. 1998;273:3158-3165.

5. Fevolt HR, Lorence MC, McCarthy JL, Trant JM, Kagimoto M, Waterman MR, Mason JI. Mol Endocrinol. 1989;3:968-975.

6. Lee-Robichaud P, Wright JN, Akhtar ME, Akhtar M. Biochem J. 1995;308:901-908.

7. Denisov IG, Makris TM, Sligar SG, Schlichting I. Chem Rev. $2005 ; 105: 2253-2277$.

8. Ghayee HK, Auchus RJ. Rev Endocr Metab Disord. 2007;8:289-300.

9. Meunier B, de Visser SP, Shaik S. Chem Rev. 2004;104:3947-3980.

10. Akhtar M, Corina DL, Miller SL, Shyadehi AZ, Wright JN. J Chem Soc, Perkin Trans 1. 1994:263-267.

Angewandte Chemie International Edition, Vol. 52, No. 20 (May 2013): pg. 5342-5345. DOI. This article is @ Wiley-VCH Verlag and permission has been granted for this version to appear in e-Publications@Marquette. Wiley-VCH Verlag does not grant permission for this article to be further copied/distributed or hosted elsewhere without the express permission from Wiley-VCH Verlag. 
NOT THE PUBLISHED VERSION; this is the author's final, peer-reviewed manuscript. The published version may be accessed by following the link in the citation at the bottom of the page.

11. Akhtar M, Wright JN, Lee-Robichaud P. J Steroid Biochem Mol Biol. 2011;125:2-12.

12. Akhtar M, Corina D, Miller S, Shyadehi AZ, Wright JN. Biochemistry. $1994 ; 33: 4410-4418$.

13. Lee-Robichaud P, Akhtar ME, Akhtar M. Biochem J. 1998;330:967-974.

14. Usanov SA, Gilep AA, Sushko TA. Biochim Biophys Acta. 2011;1814:200209.

15. Mathieu AP, LeHoux JG, Auchus RJ. Biochim Biophys Acta. 2003;1619:291-300.

16. DeVore NM, Scott EE. Nature. 2012;482:116-119.

17. Bayburt TH, Sligar SG. FEBS letters. 2010;584:1721-1727.

18. Mak PJ, Denisov IG, Grinkova YV, Sligar SG, Kincaid JR. J Am Chem Soc. 2011;133:1357-1366.

19. Denisov IG, Sligar SG. Biochim Biophys Acta. 2010;1814:223-229.

20. Atkins WM, Nath A, Grinkova YV, Sligar SG. J Biol Chem. $2007 ; 282: 28309-28320$.

21. Denisov IG, Mak PJ, Makris TM, Sligar SG, Kincaid JR. J Phys Chem A. 2008;112:13172-13179.

22. Spiro TG, Soldatova AV, Balakrishnan G. Coord Chem Rev. 2013;257:511-527.

23. Lu C, Egawa T, Wainwright LM, Poole RK, Yeh SR. J Biol Chem. 2007;282:13627-13636. [

24. Chartier FJM, Couture M. J Biol Chem. 2007;282:20877-20886.

25. Tosha T, Kagawa N, Arase M, Waterman MR, Kitagawa T. J Biol Chem. $2008 ; 283: 3708-3717$.

26. Li D, Kabir M, Stuehr DJ, Rousseau DL, Yeh SR. J Am Chem Soc. 2007;129:6943-6951.

27. Harris DL, Loew GH. J Am Chem Soc. 1998;120:8941-8948.

Angewandte Chemie International Edition, Vol. 52, No. 20 (May 2013): pg. 5342-5345. DOI. This article is @ Wiley-VCH Verlag and permission has been granted for this version to appear in e-Publications@Marquette. Wiley-VCH Verlag does not grant permission for this article to be further copied/distributed or hosted elsewhere without the express permission from Wiley-VCH Verlag. 
NOT THE PUBLISHED VERSION; this is the author's final, peer-reviewed manuscript. The published version may be accessed by following the link in the citation at the bottom of the page.

28. Ogliaro FO, de Visser SP, Cohen S, Sharma PK, Shaik S. J Am Chem Soc. $2002 ; 124: 2806-2817$.

29. Pant K, Crane BR. Biochemistry. 2006;45:2537-2544.

30. Cho KB, Gauld JW. J Phys Chem B. 2005;109:23706-23714.

31. Imai T, Globerman H, Gertner JM, Kagawa N, Waterman MR. J Biol Chem. 1993;268:19681-19689.

32. Ritchie TK, Grinkova YV, Bayburt TH, Denisov IG, Zolnerciks JK, Atkins WM, Sligar SG. Methods Enzymol. 2009;464:211-231.

33. Grinkova YV, Denisov IG, Waterman MR, Arase M, Kagawa N, Sligar SG. Biochem Biophys Res Commun. 2008;372:379-382.

\section{About the Authors}

Stephen G. Sligar : Departments of Biochemistry and Chemistry, University of Illinois, Urbana, IL, USA.

Email: s-sligar@illinois.edu

James R. Kincaid : Department of Chemistry, Marquette University Milwaukee, WI, USA.

Email: james.kincaid@marquette.edu 